\title{
ECOS SOBRE O FIM E A TERRA NENHUMA COMO DESTINO PRÓXIMO: Resenha de um Quase Manifesto
}

OLIVEIRA, Jelson; VASCONCELOS, Thiago; FROGNEUX, Nathalie. Terra Nenhuma: Ecopornografia e Responsabilidade. Caxias do Sul: EDUCS, 2020, pp. 64.

\section{Maurício Fernandes UFPI}

Em meio ao cenário de temor causado pelo avanço do novo coronavírus (COVID19) pelo mundo, e um período marcado pelo isolamento social como forma de retardar este avanço que já deixou um rastro nefasto em países como a China, Itália e, mais recentemente, os EUA - ambos com números de casos confirmados e óbitos em escala exponencial. Neste cenário marcado pela incerteza e temor imposto pela pandemia, temos a publicação da obra Terra Nenhuma, uma obra direta, clara e incisiva sobre problemas em um âmbito global que nos afetam já há alguns séculos, mas que são constantemente varridos para debaixo do tapete sob os desígnios da economia e dos impulsos do Capitalismo em sua forma atual.

A obra é composta de três artigos: Tempo e Mundo Nenhum de Thiago Vasconcelos, Ecopornografia e Responsabilidade de Jelson Oliveira, e Cassandra: A Voz do Fim de Nathalie Frogneux. Ambos transitam em um cenário marcado pela atualidade da obra de Hans Jonas e sua heurística do temor, procurando evidenciar a emergência de nossa época, os desafios e os perigos postos em nosso horizonte próximo como resultados de nossa ação sobre o mundo. A obra, em tom quase de manifesto, recoloca o problema da ameaça de extinção em decorrência da ação humana sobre o planeta. Assim como o próprio Hans Jonas, os autores podem ser situados em um ambiente marcado pelo catastrofismo que dá o tônus da obra.

Já na introdução se localiza conceitualmente a Terra Nenhuma, suas dimensões e aspectos. Os autores fazem referência à obra de David Wallace-Wells, A Terra Inabitável: Uma História do Futuro (2019), como um alerta que ecoa também em Terra Nenhuma: "Caminhamos para uma terra inabitável" (p. 09). Os autores procuram, em uma leitura densa e de fôlego, apontar para os mais variados aspectos da terra nenhuma, aspectos estes nos quais são costurados passado e presente, o local e o global, terra nenhuma é todo o globo, é onde pisamos e onde agimos.

Terra nenhuma é a terra vazia, desguarnecida e desabitada, de onde fugiram as úlitimas formas de vida, onde a vida não cresce. Terra nenhuma é negativa, da qual foi retirado o que lhe era próprio, a condição de terra (solo, planeta, território, lugar). Terra nenhuma é a terra sem futuro, arrastada pela uitilidade do passado, que lhe tirou toda fertilidade, toda chance de progresso. Terra nenhuma é terra erma, devoluta, desértica. No conceito, assim, estão as terras de Mariana e Brumadinho, arrasadas pela lama tóxica que matou gentes, bichos, rios; estão as terras dos garimpos, cuja a única herança são os buracos de água parada e morta; estão as terras amazônicas depois que a floresta veio abaixo, com suas 
cinzas e securas, sobre as quais a vida perece; estão as terras dos leitos de rios, ocas, rachadas pela aridez do tempo ou afundadas na lama tóxica e nos esgotos; estão as areias das praias cobertas de óleos; estão os oceanos e suas ilhas de plástico flutuante; todas as terras mortas do aquecimento global; as terras das usinas nucleares e seus vazamentos radioativos; as terras debaixo dos asfaltos e dos grandes prédios urbanos, escuras e chacinadas; as terras envenenadas do agronegócio e seus desertos verdes de cana, eucalipto, soja e outiras monoculturas... Não as terras utópicas, que ainda não existem, mas as terras não tópicas no sentido negativo, terra sem terra, terra sem vida, terra nenhuma, perdida de si, recusada a si, explorada, violada, estuprada. Terra de ecocídio, de desastre, de calamidades e catástrofes. Terra sem mapa e sem nome, convulsionada pelas pragas, pelas hecatombes e pelos cataclismos. Terras deslizada, movida, transportadla para outro terreno, levada à força, misturada, empobrecida, queimada; terra devastada, saqueada, profanada. Como pronome indefinido, nenhuma significa sem identidade, produto último da hostilidade e da indiferença da humanidade em relação ao seu lugar. Terra contra a qual se luitou e da qual retiroui-se qualquer noção de sentido e filnalidade. Terra destituída de valor, portanto, amassada sob os rastros dos maquinários, explorada pelos mineradores, pelos fazendeiros, madeireiros e por outros ecocidas. Terra imunda contra a qual se voltou a religião - mundo imundo. Apenas ocasião do exercício do poder humano, lugar de exploração como entretenimento. Antilugar, onde a relação eú-eú ou eu-tú é substituída por eúisso e, no limite, por isso-isso. Terra nenhuma é terra nada, ausência de realidade como ausência de futuro. Terra nenhuma é para onde caminhamos. A regra do universo, ontologia da morte flutuando em pedra morta sobre a nossa cabeça. Terra como lua. Obituário sem paisagem. Inabitável, sem mar, sem céu, sem terra, sem nada (OLIVEIRA; FROGNEUX; VASCONCELOS, 2020, pp. 10-11).

Terra nenhuma é o resto da abstração, é o que sobrou no processo de construção da imagem de mundo, é o que subjaz à imagem, nadificada. E neste processo de abstração também a vida passa a ser imagem, exposição, não a vida real, que segue vilipendiada, sem valor. Vale ressaltar que, mesmo diante da catástrofe iminente, o homem segue um ethos de finais do Antropoceno, a saber: sula relação pornográfica com a Natureza. E esta relação é tão forte que cotidianamente, em meio ao temor mundial evocado pelo novo coronavírus (COVID-19), a linguagem que traz os telejornais é a da economia, a preocupação com esta força abstrata, é como se bilhões de vidas não existissem, ou antes, como expresso por alas obscurantistas no Brasil, podem ser sacrificadas ao deus-mercado para salvar a economia (MOTA, 2020).

No primeiro artigo, Tempo e Mundo Nenhum, Thiago Vasconcelos nos traz questões relativas a um futuro possível e ao fim dos mundos, o final apocalíptico evocado pelas ações drásticas no ambiente colocam em suspenção e sob ameaça de extinção a pluralidade de mundos. A partir de uma leitura de Güinter Anders e a radicalidade da era atômica, o autor nos direciona para uma compreensão do futuro como momento no qual está, de forma indelével, inscrito o fim; seja o fim apocalíptico produzido pelo impulso bélico, seja o fim prefigurado nas catástrofes ambientais. Neste sentido, procura afirmar que uma ética do futuro deve tornar este fim infindável, ou seja, adiado (p. 19).

Potencializando um debate entre Heidegger e Jonas, o autor nos aproxima da questão da vida e sua abertura ao mundo, procurando apontar como Jonas propõe uma compreensão mais abrangente que desloca o horizonte da abertura de mundo, enquanto exclusividade do Dasein, como próximo ao homem, para uma pluralidade de mundos, ancorada em uma evolução da vida a partir do prisma da liberdade. Neste sentido, não é possível falarmos em mundo, mas em mundos plurais.

Na história humana há a construção de um mundo humano, ou de uma "humananização da Natureza", transformação de toda pluralidade de mundos em uma visão monista de um mundo humano que tritura todas as outras possibilidades de mundos. Diante deste processo é negado a todos os viventes a dignidade e respeito na 
partilha do planeta, da casa-comum (FRANCISCO, 2015), "a vida, ou, ainda, o animal, são privados de mundo" (p. 21). Assim, o autor procura discorrer sobre uma diferenciação entre a compreensão heideggeriana do animal enquanto pobre de mundo, e a ampliação jonasiana do conceito de vida a partir de uma compreensão da liberdade enquanto forma de vida, modo de existir, metabolizar, estar inscrito em um modo relacional de troca com o mundo-ambiente, circundante, Umwelt (p. 24-25).

Ao final o autor nos coloca diante de uma afirmação de que o que está em jogo é a pluralidade de mundos, o planeta permanecerá mesmo após o homem, que inevitavelmente levará consigo esta plurralidade de mundos. 0 mundo humano ameaça esta pluralidade já há alguns séculos, e ao mesmo tempo coloca o próprio humano sob o prisma da ameaça de um futuro que já se torna presente, dada a urgência das alterações no Antropoceno.

No segundo artigo, Ecopornografia e Responsabilidade de Jelson de Oliveira, somos confrontados pela voracidade com a qual exploramos o planeta, que o autor, fazendo referência ao conceito de sociedade pornográfica do filósofo sul coreano Byung Chul-Han (2014), se utiliza do conceito de pornografia estendendo-o em para uma análise de nossas ações sobre o mundo. O autor desenvolve sua análise a partir de cinco aspectos da pornografia em contextos de nossa experiência com o mundo e com nós mesmos; a saber: pornografia tecnológica, pornografia gnosiológica, pornografia ecológica, pornografia ética e pornografia política.

A pornografia tecnológica é a devastação. É a exploração ilimitada dos recursos, sujeição total e irrestrita da terra aos desejos humanos. Notemos que este pressuposto da sujeição é encarado como um imperativo divino, ao qual podemos remontar ao mandato do Gênesis: E sujeitai e dominai [a Natureza] (1:28). Esta é uma relação exposta por Friedrich Dessauer (1959), para o qual a técnica está instituída neste mandato bíblico. Sendo assim, estava aberto o caminho à exploração irrestrita. Sujeitai e dominai a terra, os oceanos e os céus. No fundo, esta exploração ilimitada segue um pressuposto teológico. A natura latina é revestida do caráter de um estofo explorável e posta sob o domínio humano, com este mesmo ímpeto teológico da exploração surgiu o Capitalismo, e atualmente seguimos piamente rumo a um fim apocalíptico com a certeza de que a eternidade é a morada. Podemos inferir que a pornografia tecnológica também é teológica.

A pornografia gnosiológica é o defloramento do mistério, do caráter sugestivo da verdade para uma fixação na superfície, na pele. O gozo é na experiência do olho, da imagem, do exposto, da nudez; o recôndito, o mistério, o inatingível, ainda manifesto na Natureza é violentado pela abstração que o nega e o aprisiona em um sistema teórico de uma razão que, em seu excesso, produz cadáveres, e antes, uma relação instrumentalizada, uma vida danificada. Como o autor aponta: "pornográfico é aquilo que se liga diretamente à imagem e o olho" (p.37). Neste sentido, transita-se na superfície, consumação do Eu-pele, da experiência da superfície do corpo (ANZIEU, 1988), "depravação da superfície", não há mais hermenêutica, mas antes uma propagação viral de fake News, de informações sem pensar, de achismos e opiniões obtusas. A pornografia gnosiológica é a violação do sentido, não há mais pensar, não há mais mistério, nada a causar admiração ou espanto, é um cancro duro no peso cego dos dias do homem em finais de seu reinado.

A pornografia ecológica é o resultado da pornografia tecnológica, é a devastação da terra, sua defloração em detrimento de interesses puramente econômicos. Vale ressaltar que os aspectos trazidos pelo autor se interpenetram, se relacionam, são causa, ação e resultado, formam um todo pornográfico, um ethos específico do homem em finais do Antropoceno.

Ao receber imperativamente o mandato do Gênesis, o homem percebeu que estava nu, teve vergonha de sua nudez, cobriu-se. Mas em sua trajetória manteve-se como um voyeur, sempre a desnudar a Natureza e a deflorar em um gozo que possui a exaustão total como fim, a morte. 
A pornografia ecológica é a insaciabilidade deste gozo, que converte a terra em objeto descartável, violentando-a inexoravelmente, exaurindo suas reservas, suas forças. A pornografia ecológica também se traduz em uma ressonância psicanalítica da violência com o corpo materno. É no corpo da mãe onde se localizam, nos innícios da vida, o prazer e o sustento. A terra como mãe, seio materno comum a todos, sucumbe aos fillhos não castrados, que a violentam sem pudor algum. E é precisamente no campo da ecologia onde a pornografia, este ethos de final do Antropoceno, concentra seus esforços no esvaziamento da terra, do outro e de si mesmo. Ecopornografia é o encontro de todas as teias relacionais da sujeição, do domínio, da violência.

A pornografia ética é a perda da morada, mas uma perda gozada, irrefletidamente, é a imagem que nos traz o autor, do "homem [que] corta o galho em que está sentado, e sem nenhum embaraço ou culpa" (p.44).

A pornografia política é resultado da transformação da pornografia da técnica e também ética. É neste âmbito em que todas faces da relação pornográfica com a terra se transformam em morte, em necropolítica, em necroética. É neste campo que são imoladas as últimas reservas de floresta, de comunidades tradicionais, de biodiversidade, no altar do deus-mercado.

O autor, ao final contrapõe a pornografia ao erotismo, tendo neste último uma possibilidade de uma relação mais coerente com a Natureza, como "uma aprovação radical da vida no encontro com os outros seres, com os quais dividimos pertencimentos" (p. 50).

O último artigo, creio propositadamente posicionado ao final, é de Nathalie Frogneux, intitulado Cassandra: a voz do fim, pois assim, em um crescendo a obra lança uma voz, que talvez como tantas outras não seja ouvida, mas uma voz que anuncia a proximidade do fim, proximidade da terra nenhuma, vazia. Como uma lanterna, nos aponta o estado em que nos encontramos: "para que agir, se é, daqui em diante impossível produzir consequências que inverterão o curso das coisas?" (p. 60).

40 anos após a publicação da obra O Princípio responsabilidade, a voz de Jonas segue atual e agudizada por uma gama de problemas novos e urgentes. $O$ que aconteceu no mundo? O que acontece com o mundo? O que acontecerá? O mundo para o qual Jonas direcionou sua voz ampliou seu poder e também o perigo da catástrofe.

A autora nos aponta que os "erros" do diagnóstico de Jonas centram-se na descrição da crise "em um estado menos avançado que este que conhecemos atualmente" (p. 53), e a esperança de que um caráter propedêutico das pequenas catástrofes levaria a uima "mudança de comportamento massiva" (p. 55). 40 anos após, sua voz permanece vívida, juntando-se à outras que, tal como Cassandra, anuncia um fim que já se avizinha no horizonte, porém, tais vozes parecem inaudíveis e o grande desafio desta época marcada pela emergência é, como aponta a autora:

Como fazer ouvir um discurso que ninguém deseja ouvir, que os destinatários recusam ouviir a ponto de preferirem negar a previsão sustentada cientificamente, em razão de seu caráter catastrófico e se agarrar desesperadamente a uima ilusão reconfortante? (

Esta afirmação se aproxima da realidade brasileira atual, como uma descrição da necropolítica que assola o país, vilipendiando a vida, difundindo um discurso torpe que segue interesses claros de exploração de reservas indígenas, de florestas protegidas por lei. Como fazer ouvir essa voz da emergência para um governo que demite cientista e desestabiliza a pesquisa científica para alimentar opiniões medíocres sobre aquecimento global e desmatamento da floresta amazônica? Como fazer ouvir esta voz a um país que entregou sua diplomacia internacional à lunáticos que acreditam ser o aquecimento global uma trama marxista para dominar o mundo?

Há uma voz que ecoa desde Cassandra, e que a autora capta unindo a heurística jonasiana e o discurso de Greta Thunberg, aqui cabem outras tantas vozes, todas como uma seta direcionada a uma sociedade pornograficamente inerte, entregue a seu próprio 
gozo da exploração e do consumo desenfreado, que presente o fim, e mesmo, já se dá conta da proximidade, mas prefere fingir e aguardar algum Deus ex machina para resolver a trama universal.

Uma obra, como apontam os autores, que é quase um manifesto, pois recupera esta voz por vezes suprimida ou esquecida, uma voz-alarme que soa vívida desde a segunda metade do século XX, a voz de Cassandra atualizada. Uma leitura necessária para nossos dias de isolamento social em decorrência do novo coronavírus (COVID-19), e que certamente traz muitas reflexões sobre nossa relação com a Terra.

\section{Referências}

ANZIEU, Didier. O Eu-pele. São Paulo: Casa do Psicólogo, 1988.

DESSAUER, Friedrich. Streit um die Technik. Herder-Bucherei: Freiburg im Breisgau, 1959 .

FRANCISCO. Carta Encíclica Laudato Si - Sobre o Cuidad da Casa Comum. 24 maio 2015. Roma. Disponível em: http://www.vatican.va/content/francesco/pt/encyclicals/documents/papafrancesco_20150524_enciclica-laudato-si.html. Acessado em: 02/04/2020.

HAN, Byung-Chul. A Sociedade da Transparência. Lisboa: Relógio D’Água, 2014, p. 73.

MOTA, Erick. “O Brasil não Pode Parar por 5 ou 7 mil mortes”, diz Dono do Madero. Congresso em Foco. 23 março 2020. Disponível em: Acesso em: 03/04/2020. Disponível em: https://congressoemfoco.uol.com.br/economia/brasil-não-pode-parar-por-cinco-ousete-mil-mortes-diz-dono-do-madero/. Acesso em: 02/04/2020. 